\title{
The Medieval Climate Anomaly and Little Ice Age in Chesapeake Bay and the North Atlantic Ocean
}

\author{
T.M. Cronin ${ }^{\text {a,* }}$, K. Hayo ${ }^{\text {b }}$, R.C. Thunell ${ }^{\text {c }}$, G.S. Dwyer ${ }^{\text {d }}$, C. Saenger ${ }^{\text {e }}$, D.A. Willard ${ }^{\text {a }}$ \\ a 926A US Geological Survey National Center, Reston, VA 20192, USA \\ b Institute of Arctic and Alpine Research, University of Colorado, Boulder, CO 80320, USA \\ c Department of Earth and Ocean Sciences, University of South Carolina, Columbia, SC 29208, USA \\ d Division of Earth and Ocean Sciences, Nicholas School of the Environment, Duke University, Durham, NC 27708, USA \\ e Woods Hole Oceanographic Institution, Woods Hole, MA 02543, USA
}

\section{A R T I C L E I N F O}

\section{Article history:}

Received 21 May 2010

Received in revised form 17 August 2010

Accepted 18 August 2010

Available online 22 August 2010

\section{Keywords:}

Medieval Climate Anomaly

Little Ice Age

Chesapeake Bay

Holocene climate

\begin{abstract}
A B S T R A C T
A new 2400-year paleoclimate reconstruction from Chesapeake Bay (CB) (eastern US) was compared to other paleoclimate records in the North Atlantic region to evaluate climate variability during the Medieval Climate Anomaly (MCA) and Little Ice Age (LIA). Using $\mathrm{Mg} / \mathrm{Ca}$ ratios from ostracodes and oxygen isotopes from benthic foraminifera as proxies for temperature and precipitation-driven estuarine hydrography, results show that warmest temperatures in $\mathrm{CB}$ reached $16-17^{\circ} \mathrm{C}$ between 600 and $950 \mathrm{CE}$ (Common Era), centuries before the classic European Medieval Warm Period (950-1100 CE) and peak warming in the Nordic Seas (1000-1400 CE). A series of centennial warm/cool cycles began about 1000 CE with temperature minima of $\sim 8$ to $9^{\circ} \mathrm{C}$ about 1150,1350 , and $1650-1800 \mathrm{CE}$, and intervening warm periods $\left(14-15^{\circ} \mathrm{C}\right)$ centered at 1200, 1400, 1500 and 1600 CE. Precipitation variability in the eastern US included multiple dry intervals from 600 to $1200 \mathrm{CE}$, which contrasts with wet medieval conditions in the Caribbean. The eastern US experienced a wet LIA between 1650 and 1800 CE when the Caribbean was relatively dry. Comparison of the $\mathrm{CB}$ record with other records shows that the MCA and LIA were characterized by regionally asynchronous warming and complex spatial patterns of precipitation, possibly related to ocean-atmosphere processes.
\end{abstract}

Published by Elsevier B.V.

\section{Introduction}

Northern Hemispheric atmospheric temperature reconstructions for the past two millennia show a distinct warm period centered on 1000-1100 CE (Common Era and BCE = before CE), called the Medieval Climate Anomaly (MCA, also called Medieval Warm Period, MWP), that contrasts with cooler climate during the Little Ice Age 1400-1850 CE (Jones and Mann, 2004). Medieval climate was also characterized by hydrometeorological variability across North America (Cook et al., 2007) and Eurasia (Treydte et al., 2006). Solar and volcanic activity (Crowley, 2000; Ammann et al., 2007), solar-oceanic feedbacks (Bond et al., 2001), ocean circulation (Broecker, 2001), Pacific Ocean-atmospheric processes (Cook et al., 2007), and land-use changes (Goosse et al., 2006; Ruddiman, 2007) have all been proposed as factors influencing MCA-LIA climate.

In a recent global paleoclimate-modeling study, Mann et al. (2009) concluded that MCA-LIA temperature variability was influenced by both solar and volcanic radiative forcing and internal climate processes, but they called for additional proxy records to improve regional model

\footnotetext{
* Corresponding author. Tel.: +1 703648 6363; fax: +1 7036485420 .

E-mail address: tcronin@usgs.gov (T.M. Cronin).
}

projections of future climate. For example, of more than 1200 proxy reconstructions used in their compilation, only 25 records covered the last 2000 years and only a few were from marine sediments (see Mann et al., 2008). Given the potential importance of ocean circulation in driving late Holocene climate (Newton et al., 2006; Oppo et al., 2009), additional high-resolution ocean records are sorely needed. In this study, new temperature and precipitation reconstructions from MarionDufresne core MD03-2661, a 24.5 m-long core from Chesapeake Bay (CB) containing sediments deposited during the past $10 \mathrm{ka}$ are compared to other proxy records from the North Atlantic region to examine the amplitude and timing of regional climate variability during the last 2400 years. As such, it represents a small step toward the integration of the ocean records into late Holocene climate reconstructions.

\section{Regional setting}

\subsection{Chesapeake Bay hydrography}

CB is a $320 \mathrm{~km}$-long, $6500 \mathrm{~km}^{2}$ estuary located in the mid-Atlantic region of the eastern US (Fig. 1). Density-driven CB circulation is influenced by freshwater river discharge and inflowing marine water. Susquehanna River water, which accounts for up to $62 \%$ of the total 
a

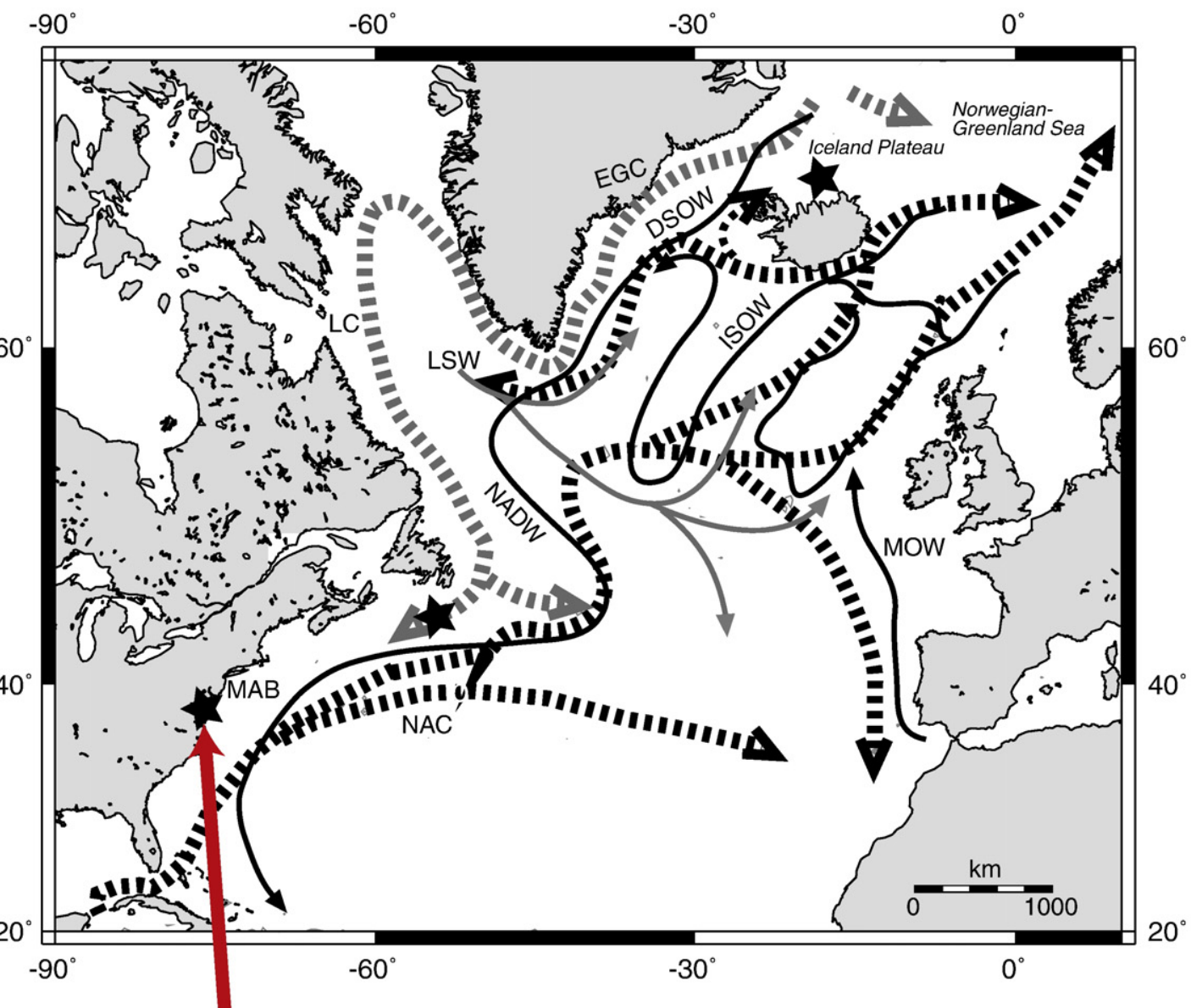

b

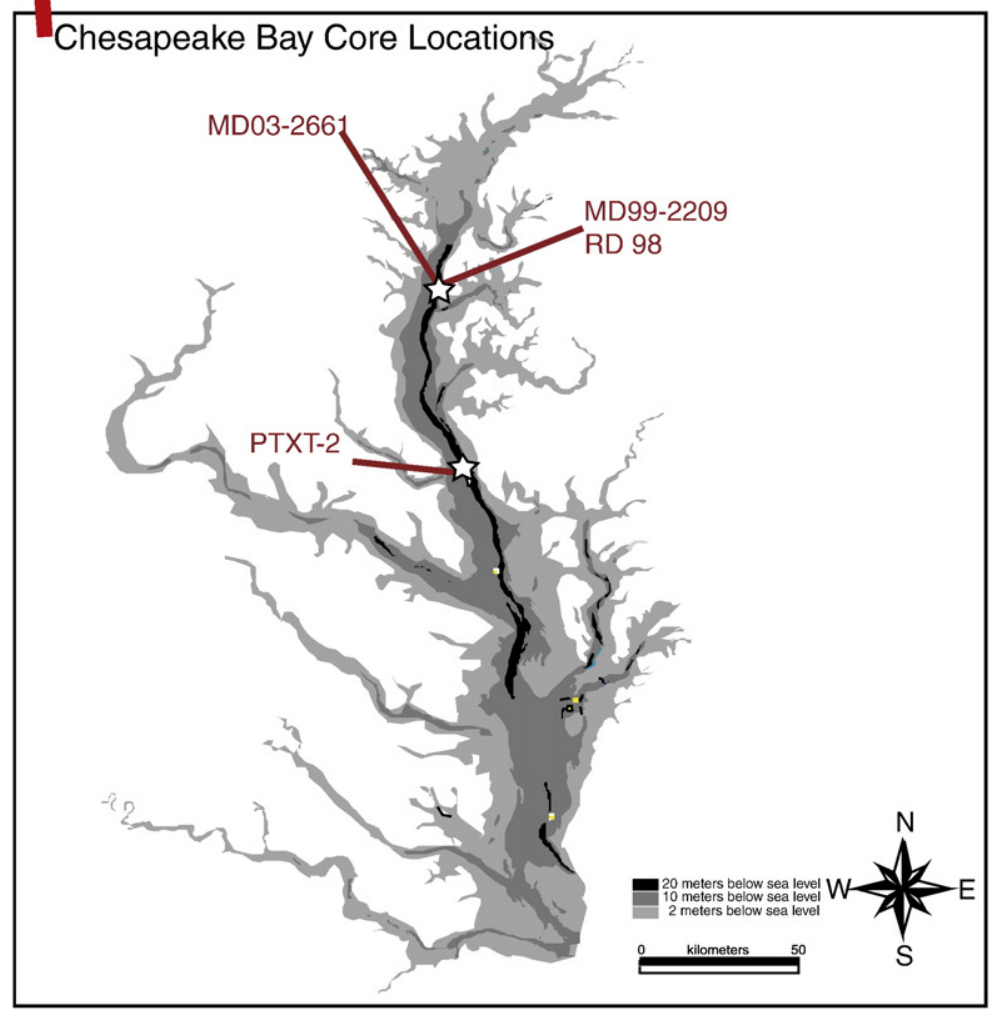

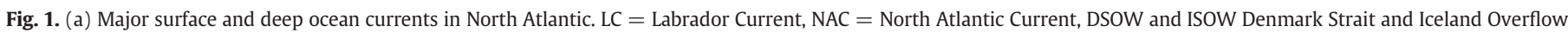

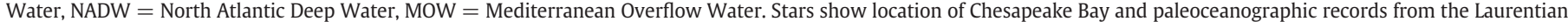


omc_intro.html). (b) Chesapeake Bay and location of sediment cores. MAB is Mid-Atlantic Bight region of continental shelf. 


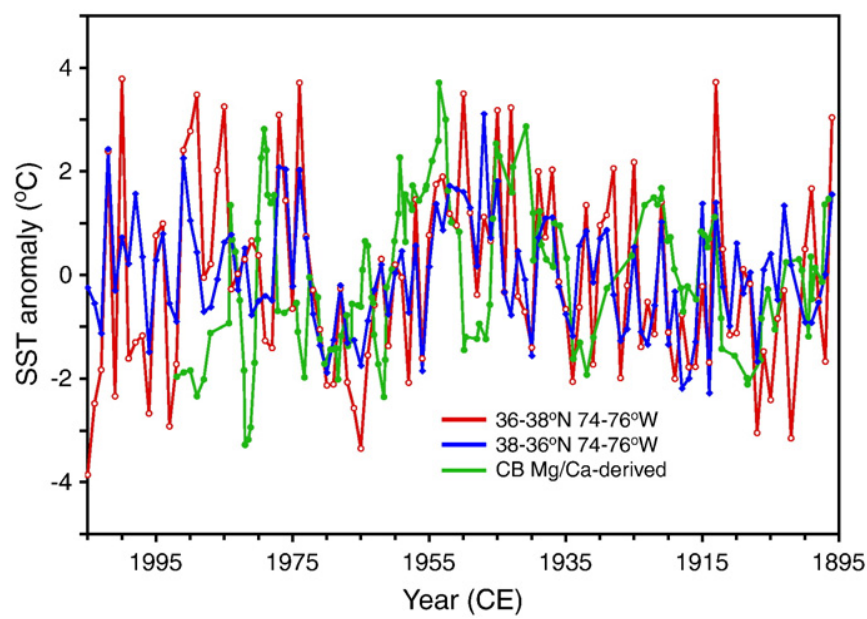

Fig. 2. April sea-surface temperature (SST) anomalies $\left({ }^{\circ} \mathrm{C}\right)$ off eastern North America from grids latitude $36-38^{\circ}$ longitude $74-76^{\circ}$ (red line) and $38-40^{\circ}$ latitude, $74-76^{\circ}$ longitude (blue line) compared to $\mathrm{Mg} / \mathrm{Ca}$-derived paleotemperature curve (5-point smoothing) from Chesapeake Bay sediment cores (green line). Instrumental records from International Comprehensive Ocean-Atmospheric Data Sets (ICOADS) represent SST trends in source area for Chesapeake Bay marine water. Sedimentation and bioturbation preclude a year-to-year comparison of proxy and instrumental records, but both show decadal temperature oscillations of 3-6 ${ }^{\circ} \mathrm{C}$ reflecting large-scale North Atlantic Ocean temperature patterns, such as the relatively warm 1940s, 1950s and 1970s and cool 1960s. Analyses of January ICOADs datasets (not shown) reveal similar temperature oscillations. (For interpretation of the references to color in this figure legend, the reader is referred to the web version of this article.)

freshwater input, enters the bay in the north and exerts a dominant control over circulation (Gibson and Najjar, 2000). Ocean water enters the bay from the Mid-Atlantic Bight (MAB) on the adjacent continental shelf such that mixing of freshwater from the north and ocean water from the south results in a stratified water column that overshadows short-term effects of tides, wind, storms and topography over interannual and decadal timescales (Boicourt et al., 1999). Rainfall and river discharge also influence the bay's oxygen isotopic composition ( $\left.\delta^{18} \mathrm{O}_{\text {baywater }}\right)$, as isotopically depleted freshwater water ( -7 to $-9 \%$ ) mixes with enriched marine water ( $0 \%$ o). To a first approximation, more rainfall leads to greater discharge, a stronger pycnocline, lower salinity, and depleted $\delta^{18} \mathrm{O}$ values; however bottom waters are more strongly influenced by more saline, denser marine water (Cronin et al., 2005).

\subsection{Regional oceanography}

The source of $\mathrm{CB}$ marine water is an important factor when interpreting its temperature record. Fig. 1 shows the major surface and deep ocean currents in the North Atlantic Ocean, their location with respect to the $M A B$, and the location of paleoceanographic records discussed below. Stable isotopic (Chapman and Beardsley, 1989; Houghton and Fairbanks, 2001) and oceanographic evidence (Petrie and Drinkwater, 1993; Dickson et al., 2002) shows that MAB water is the southern endmember of a 5000-km long, coastal current that flows southwest from subarctic regions (East Greenland Current) through the Labrador Sea, Scotian Shelf, and Gulf of Maine and into the MAB. The Labrador Current (LC), a branch of Labrador Sea Water formed near the shelf/slope break off maritime Canada, is an important distal source of MAB-Chesapeake Bay water. On decadal timescales, the strength of the LC is linked to i) North Atlantic Oscillation (NAO) decadal climate variability, ii) the Atlantic Meridional Overturning Circulation (AMOC) including Labrador Sea deep-water formation, and iii) wind-driven processes in the North Atlantic (e.g., Dickson et al., 2002). Thus, bay temperature variability should reflect that of its source water in the MAB, and more broadly, ocean-atmosphere

Table 1

Studies of Chesapeake Bay sediment core chronology and deposition rates.

\begin{tabular}{|c|c|c|c|c|}
\hline Method & Time interval & Issue & Comment & References \\
\hline${ }^{137}$ Cesium & Since $\sim 1960$ & $\begin{array}{l}\text { 1963-64 cesium peak and influence } \\
\text { of bioturbation }\end{array}$ & $\begin{array}{l}\text { Cesium peak evident, bioturbation minor } \\
{[<1 \mathrm{~cm}]}\end{array}$ & 1 \\
\hline${ }^{210} \mathrm{~Pb}$ & Since $\sim 1900$ & 20th century sediment rate and bioturbation & $\begin{array}{l}\text { Mass accumulation rates, cesium and pollen, } \\
\text { bioturbation minimal }\end{array}$ & 1 \\
\hline Pollen stratigraphy and land use & Since $\sim 1700 \mathrm{CE}$ & Historical sedimentation rates & $\begin{array}{l}\text { Consistent with cesium and lead data and } \\
\text { historical land clearance }\end{array}$ & 2 \\
\hline $\begin{array}{l}{ }^{14} \mathrm{C} \text { dating museum shells collected } \\
\text { before nuclear testing }\end{array}$ & since $\sim 1850$ C.E. & Local reservoir effects $(\Delta R)$ & $\begin{array}{l}3 \text { shells dated at } 365+/-143 \text { years; about }=\text { mean } \\
\text { ocean reservoir effect }\end{array}$ & 3 \\
\hline $\begin{array}{l}{ }^{14} \mathrm{C} \text { dating shells from sediment } \\
\text { deposited during colonial period }\end{array}$ & $\sim 1700-1900$ & Local reservoir effects $(\Delta R)$ & No local reservoir correction & 4 \\
\hline Multiple methods & Since $\sim 1700 \mathrm{CE}$ & Historical sedimentation rates & Colonial land clearance increased sedimentation rates & 5 \\
\hline${ }^{13} \mathrm{C}$ from mollusks and foraminiferas & Holocene & $\begin{array}{l}\text { Influence of dissolved organic c } \\
\text { arbon [DIC] }\end{array}$ & $\begin{array}{l}\text { Mollusk }{ }^{13} \mathrm{C} \text { values } \sim-1 \text { to } 0 \% \text {; foram } \sim-3 \text { to }-1 \% \text {; } \\
\text { no DIC influence }\end{array}$ & $3,6,7$ \\
\hline $\begin{array}{l}{ }^{14} \mathrm{C} \text { dating organic carbon }(\mathrm{OC}) \\
\text { (pollen, fish scales, wood) }\end{array}$ & Holocene & Old carbon effects & OC ages $1500-2000$ years too old; not used in chronology & 3 \\
\hline X-radiographs & Holocene & Bioturbation and burrowing & Burrowing mainly in shallow water cores & 1,8 \\
\hline${ }^{14} \mathrm{C}$ dating Holocene mollusks & Holocene & Downcore chronology & $\begin{array}{l}\text { No age reversals, }>0.9 r^{2} \text { age-depth, calibrated age } \\
\text { error } \sim 100-200 \text { years }\end{array}$ & 1,3 \\
\hline${ }^{14} \mathrm{C}$ ages on Mulinia [mollusk] RD-2209 & Holocene & 10 dates from $296-780 \mathrm{~cm}$ core depths & No age reversals, $>0.9 \mathrm{r}^{2}$ age-depth model & 4,6 \\
\hline${ }^{14} \mathrm{C}$ ages on Mulinia [mollusk] MD03-2661 & Holocene & 10 dates from $89-1003 \mathrm{~cm}$ core depths & No age reversals, $>0.9 r^{2}$ age-depth model & 7 \\
\hline Amino acid dating & Holocene & Sedimentation rates & Supports radiocarbon chronology & 9 \\
\hline $\begin{array}{l}\text { Physical stratigraphy and shell } \\
\text { preservation }\end{array}$ & Holocene & Burrowing and reworking & Negligible in deep channel, important in shallow water & 8,10 \\
\hline
\end{tabular}

1 - Karlsen et al. (2000), Cronin et al. (2000), Zimmerman and Canuel (2002).

2 - Brush (1989), Willard et al. (2003).

3 - Colman et al. (2002).

4 - Willard et al. (2005).

5 - Colman and Bratton (2003), Bratton et al. (2003), Saenger et al. (2008).

6 - Cronin et al. 2003, 2005.

7 - Cronin et al. (2007).

8 - Kerhin et al. (1998).

9 - Edwards (2007).

10 - Cronin (2000).

Note: Above references contain additional citations to cesium-137, lead-210 and pollen studies. 


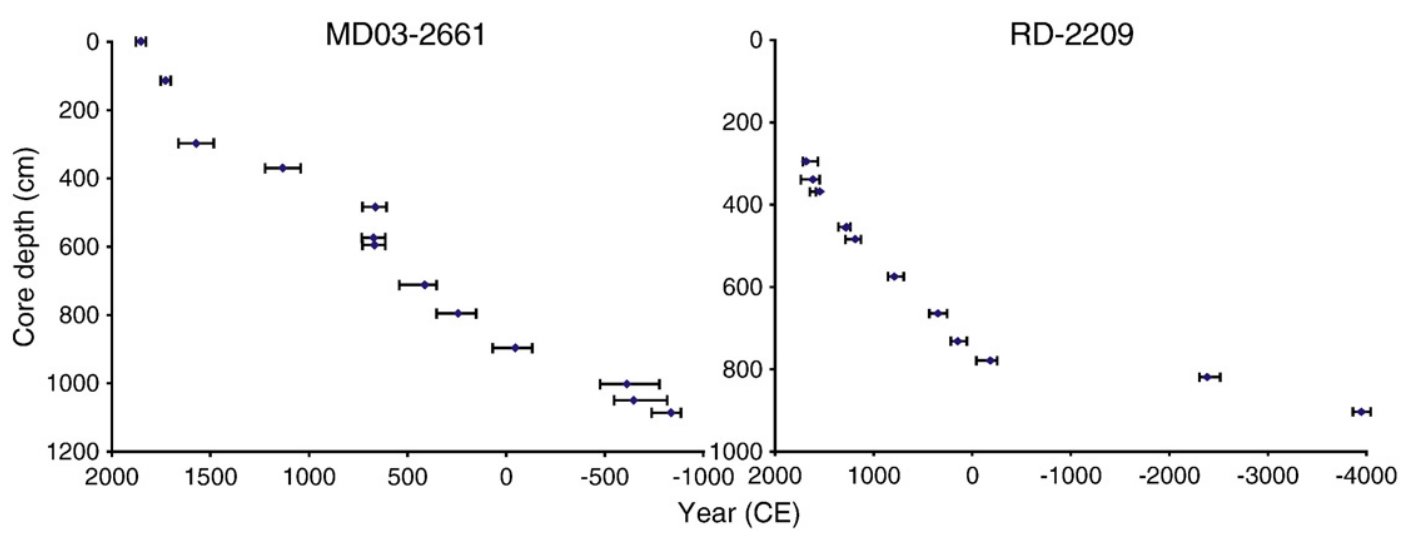

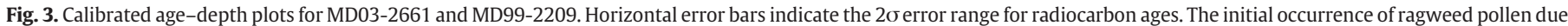

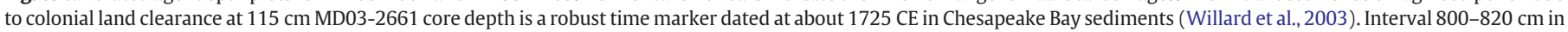
MD99-2209 is condensed zone. Age model for MD03-2661 samples calculated from core depth as follows: $\left(0.0008 *\right.$ depth $\left.^{2}\right)-(1.5417 *$ depth $)+1884.3\left(\mathrm{r}^{2}=0.981\right)$.

processes originating in subpolar regions of the Northern Hemisphere. This hypothesis is further discussed in the section on proxy methods.

\section{Material and methods}

\subsection{Sediment cores}

Sediment cores for this study were taken in the Chesapeake Bay aboard the R/V Marion-Dufresne during IMAGES cruises in 1999 and 2003 and earlier cruises with the R/V Kerhin (Kerhin et al., 1998; Cronin et al., 2000; Karlsen et al., 2000) (Fig. 1 inset). These include a 17.2-m long core MD99-2209 $\left(38^{\circ} 53.18^{\prime} \mathrm{N}\right.$ and $76^{\circ} 23.68^{\prime} \mathrm{W}$, water depth $25 \mathrm{~m}$ ), nearby core RD-98 (Colman et al., 2002) and core PTXT-2 from off the Patuxent River $\left(38^{\circ} 19.58^{\prime} \mathrm{N}\right.$ and $76^{\circ} 23.55^{\prime} \mathrm{W}$, water depth $11.5 \mathrm{~m}$ ) that produced the paleotemperature record discussed in Cronin et al. (2003). This composite curve, referred to as RD-2209, covers the last 2200 years and has been incorporated into several northern hemisphere surface temperature reconstructions covering the last 2000 years (e.g. Mann and Jones, 2003; Moberg et al., 2005; Mann et al., 2008). However, RD-2209 is a composite of four cores, and one (PTXT-2) that covers the critical Little Ice Age comes from shallower water and a different location than other cores. The new, continuous paleoclimate record is presented below from MD03-2661 $\left(38^{\circ} 53.21^{\prime} \mathrm{N}\right.$ and $\left.76^{\circ} 23.89^{\prime} \mathrm{W}\right)$ taken in $\mathrm{CB}$ in 2003 . MD03-2661 is located near and at the same water depth (25 m) as MD99-2209, and its uppermost $10 \mathrm{~m}$ provides a continuous record of the MCA and LIA with 2 to 12-year sampling resolution. MD03-2661 and RD-2209 together allow a more critical evaluation of centennial variability in temperature and precipitation during this period.

\subsection{Proxy methods}

Ostracode $\mathrm{Mg} / \mathrm{Ca}$ and benthic foraminifer oxygen isotopes $\left(\delta^{18} \mathrm{O}_{\text {foram }}\right)$ were used as proxies of warm-season temperature and estuarine hydrography, respectively. The shallow water genus Loxoconcha is among several marine ostracode taxa whose shell $\mathrm{Mg} / \mathrm{Ca}$ ratios have been used as paleothermometers (Dwyer et al., 2002). Between two and ten adult valves of Loxoconcha from 2-cm spaced samples from MD032661 were analyzed for $\mathrm{Mg} / \mathrm{Ca}$ ratios at Duke University on a Spectrospan 7 direct current plasma emission spectrometer. A total of 258 samples from MD03-2661 yielded L. matagordensis suitable for analysis (see chronology); the RD-2209 record included 450 analyses (Cronin et al., 2003). $\mathrm{Mg} / \mathrm{Ca}$ ratios were converted to warm-season temperature using the calibration equation $\mathrm{y}=0.644 \mathrm{x}-2.4284\left(\mathrm{r}^{2}=0.805\right)$ derived from field, culturing and laboratory analyses of Loxoconcha from Chesapeake Bay and the adjacent continental shelf (Dwyer et al., 2002; Cronin et al., 2003; Vann et al., 2004). These calibration studies demonstrated that temperature is the primary factor influencing Chesapeake Bay Loxoconcha $\mathrm{Mg} / \mathrm{Ca}$ ratios and, at least over the sampled salinity range ( 15$35 \mathrm{psu})$, salinity does not appear to be important.

To validate the field and lab-based $\mathrm{Mg} / \mathrm{Ca}$-temperature calibration, the part of the RD-2209 paleotemperature curve covering the last century was compared to International Comprehensive Ocean-Atmospheric Data Sets (ICOADS) instrumental SST records from two grid cells (latitude $36-38^{\circ}$ longitude $74-76^{\circ}$ and $38-40^{\circ}$ latitude, $74-76^{\circ}$ ) located off eastern North America in source regions of CB marine water (Fig. 2). Despite age uncertainty in the sediment record, both proxy and instrumental records show decadal temperature anomalies of $3-6{ }^{\circ} \mathrm{C}$, including warm periods during the 1940s, 1950s and 1970s and cool period during the 1960s and early 20th century. These regional decadal oscillations are typical of basin-scale atmospheric-oceanic temperature variability associated with the North Atlantic Oscillation, supporting the idea that the bay and its source water reflect large, basin-scale processes. It is also important to note that the amplitude of decadal ocean temperature variability in both the instrumental and proxy records is large compared to that observed in tree-ring-based mean Northern Hemisphere surface atmospheric temperature reconstructions discussed below.

Foraminiferal $\delta^{18} \mathrm{O}$ is generally controlled by water temperature and the oxygen isotope composition of seawater in which the foraminifera calcified. In $\mathrm{CB}$, the $\delta^{18} \mathrm{O}_{\text {baywater }}$ mainly reflects discharge-driven hydrological variability and the mixing of fresh and marine endmembers, which influences the $\delta^{18} \mathrm{O}$ of bay benthic foraminifera ( $\left.\delta^{18} \mathrm{O}_{\text {foram }}\right)$ (Cronin et al., 2005; Saenger et al., 2006). Five to ten specimens of the benthic foraminifera Elphidium selseyense were analyzed from each MD03-2661 sample for $\delta^{18} \mathrm{O}$ at the University of South Carolina stable isotope lab using a GV Isoprime stable isotope ratio mass spectrometer. The long-term standard reproducibility is $0.07 \%$ for $\delta^{18} \mathrm{O}$ and results are reported relative to Vienna Pee Dee Belemnite (V-PDB). A total of 488 isotopic analyses were performed yielding a temporal resolution of about 5 years (see chronology). Paired downcore foraminiferal isotope and ostracode $\mathrm{Mg} / \mathrm{Ca}$ measurements for 354 samples yielding both measurements were used to correct $\delta^{18} \mathrm{O}_{\text {foram }}$ values for temperature and to estimate $\delta^{18} \mathrm{O}_{\text {baywater }}$ following methods in Cronin et al. (2005).

\subsection{Chronology}

Estuarine sediment records can provide high-resolution paleoclimate records, but attention must be paid to processes that influence sedimentation, radiocarbon ages, and other chronologic markers. A large literature on CB sediments, summarized in Table 1, includes studies of stratigraphy, sediment geochemistry, CHIRP sonar geophysical records, X-radiographs of bioturbation, and radiocarbon dating of 
Table 2

Radiocarbon dates from MD03-2661 core, Chesapeake Bay.

\begin{tabular}{|c|c|c|c|c|c|c|c|c|c|c|c|c|c|c|}
\hline $\begin{array}{l}\text { Date } \\
\text { number* }\end{array}$ & Core & $\begin{array}{l}\text { Water depth } \\
(\mathrm{m})\end{array}$ & $\begin{array}{l}\text { Sample depth } \\
(\mathrm{cm})\end{array}$ & $\begin{array}{l}\text { Midpoint depth } \\
(\mathrm{cm})\end{array}$ & $\begin{array}{l}\text { Latitude } \\
(\mathrm{N})\end{array}$ & $\begin{array}{l}\text { Longitude } \\
\text { (W) }\end{array}$ & Material dated & $\delta^{13} \mathrm{C}$ & $\begin{array}{l}{ }^{14} \mathrm{C} \text { age } \\
\text { (conventional) }\end{array}$ & $\begin{array}{l}\text { Error } \\
+/-B P\end{array}$ & $\begin{array}{l}\text { Calibrated age } \\
\text { (yr BP) }\end{array}$ & $\begin{array}{l}\text { Calibrated }+2 \sigma \\
\text { (yr BP) }\end{array}$ & $\begin{array}{l}\text { Calibrated }-2 \sigma \\
\text { (yr BP) }\end{array}$ & Common Era age \\
\hline NA & MD03-2661 & 25.5 & 0 & 0 & 3853.21 & 7623.89 & Pollen Stratigraphy & $\mathrm{N} / \mathrm{A}$ & $\mathrm{N} / \mathrm{A}$ & $\mathrm{N} / \mathrm{A}$ & $\mathrm{N} / \mathrm{A}$ & N/A & $\mathrm{N} / \mathrm{A}$ & 1850-1880 \\
\hline B-235942 & MD03-2661 & 25.5 & $86-92$ & 89 & 3853.21 & 7623.89 & Mulinia lateralis & -1.3 & 240 & 40 & $\mathrm{~N} / \mathrm{A}$ & $\mathrm{N} / \mathrm{A}$ & $\mathrm{N} / \mathrm{A}$ & Post 18 th cent. \\
\hline NA & MD03-2661 & 25.5 & 115 & 115 & 3853.21 & 7623.89 & Pollen Stratigraphy & $\mathrm{N} / \mathrm{A}$ & $\mathrm{N} / \mathrm{A}$ & $\mathrm{N} / \mathrm{A}$ & $\mathrm{N} / \mathrm{A}$ & $\mathrm{N} / \mathrm{A}$ & $\mathrm{N} / \mathrm{A}$ & $\sim 1725$ \\
\hline B-235943 & MD03-2661 & 25.5 & $188-194$ & 191 & 3853.21 & 7623.89 & Mulinia lateralis & -0.6 & 320 & 40 & $\mathrm{~N} / \mathrm{A}$ & $\mathrm{N} / \mathrm{A}$ & $\mathrm{N} / \mathrm{A}$ & Post 18 th cent. \\
\hline B-235944 & MD03-2661 & 25.5 & 296-302 & 299 & 3853.21 & 7623.89 & Mulinia lateralis & -2.2 & 740 & 40 & 380 & 470 & 290 & 1570 \\
\hline 180325 & MD03-2661 & 25.5 & $370-372$ & 371 & 3853.21 & 7623.89 & Mulinia lateralis & -1.4 & 1280 & 40 & 820 & 910 & 730 & 1130 \\
\hline 181991 & MD03-2661 & 25.5 & 485 & 485 & 3853.21 & 7623.89 & Mulinia lateralis & -1.5 & 1750 & 40 & 1290 & 1355 & 1235 & 660 \\
\hline 191408 & MD03-2661 & 25.5 & $574-576$ & 575 & 3853.21 & 7623.89 & Mulinia lateralis & -1.4 & 1730 & 40 & 1280 & 1340 & 1220 & 670 \\
\hline 181992 & MD03-2661 & 25.5 & 597 & 597 & 3853.21 & 7623.89 & Mulinia lateralis & -1.3 & 1740 & 40 & 1285 & 1345 & 1230 & 665 \\
\hline 191409 & MD03-2661 & 25.5 & $712-714$ & 713 & 3853.21 & 7623.89 & Mulinia lateralis & -1.4 & 2000 & 40 & 1540 & 1670 & 1480 & 410 \\
\hline 191410 & MD03-2661 & 25.5 & $796-798$ & 797 & 3853.21 & 7623.89 & Mulinia lateralis & -0.4 & 2140 & 40 & 1710 & 1820 & 1620 & 240 \\
\hline 181993 & MD03-2661 & 25.5 & 898 & 898 & 3853.21 & 7623.89 & Mulinia lateralis & -1.8 & 2390 & 40 & 2000 & 2115 & 1915 & -50 \\
\hline 181994 & MD03-2661 & 25.5 & 1003 & 1003 & 3853.21 & 7623.89 & Mulinia lateralis & -1.5 & 2810 & 40 & 2565 & 2700 & 2400 & -615 \\
\hline 191411 & MD03-2661 & 25.5 & $1052-1054$ & 1053 & 3853.21 & 7623.89 & Mulinia lateralis & -0.4 & 2820 & 40 & 2600 & 2700 & 2430 & -650 \\
\hline 180326 & MD03-2661 & 25.5 & $1086-1089$ & 1087.5 & 3853.21 & 7623.89 & Mulinia lateralis & -0.6 & 3050 & 40 & 2790 & 2890 & 2740 & -840 \\
\hline 215879 & MD03-2661 & 25.5 & $1146-1148$ & 1147 & 3853.21 & 7623.89 & Seed & N/A & 3420 & 40 & 3670 & 3820 & 3580 & -1720 \\
\hline 215880 & MD03-2661 & 25.5 & $1150-1155$ & 1152.5 & 3853.21 & 7623.89 & Shell & -1.2 & 3940 & 40 & 3910 & 4050 & 3820 & -1960 \\
\hline 191412 & MD03-2661 & 25.5 & $1216-1218$ & 1217 & 3853.21 & 7623.89 & Mulinia lateralis & -0.7 & 5160 & 40 & 5560 & 5590 & 5450 & -3610 \\
\hline 191413 & MD03-2661 & 25.5 & $1300-1302$ & 1301 & 3853.21 & 7623.89 & Mulinia lateralis & -0.3 & 5440 & 50 & 5840 & 5910 & 5690 & -3890 \\
\hline 191414 & MD03-2661 & 25.5 & $1398-1400$ & 1399 & 3853.21 & 7623.89 & Mulinia lateralis & -0.7 & 5530 & 40 & 5910 & 5980 & 5850 & -3960 \\
\hline 191415 & MD03-2661 & 25.5 & $1412-1414$ & 1413 & 3853.21 & 7623.89 & Mulinia lateralis & -0.2 & 5520 & 50 & 5900 & 5990 & 5770 & -3950 \\
\hline 191416 & MD03-2661 & 25.5 & $1458-1460$ & 1459 & 3853.21 & 7623.89 & Mulinia lateralis & -0.6 & 5590 & 40 & 5950 & 6080 & 5900 & -4000 \\
\hline 180327 & MD03-2661 & 25.5 & 1476 & 1476 & 3853.21 & 7623.89 & Mulinia lateralis & -1 & 5600 & 40 & 5970 & 6090 & 5900 & -4020 \\
\hline 191417 & MD03-2661 & 25.5 & $1614-1616$ & 1615 & 3853.21 & 7623.89 & Mulinia lateralis & -0.7 & 5820 & 40 & 6260 & 6300 & 6170 & -4310 \\
\hline
\end{tabular}

All dates National Ocean Science Accelerator mass Spectrometry Facility (NOSAMS), Woods Hole Oceanographic except "B-" from Beta Analytic.

Radiocarbon dates calibrated using marine calibration curve from Stuiver et al. (1998) with no $\Delta R$ correction and assuming no change in $\Delta R$ over the last 2400 years.

Further discussion of Chesapeake core chronology can be found in Cronin T.M. et al. (2007). Geophys. Res. Lttrs., 34, L20603.

Willard et al. (2003). The Holocene, 13, 201-214.

Willard et al. (2005). Glob. Planet Change, 47, 17-35.

$\mathrm{NA}=$ not available. 


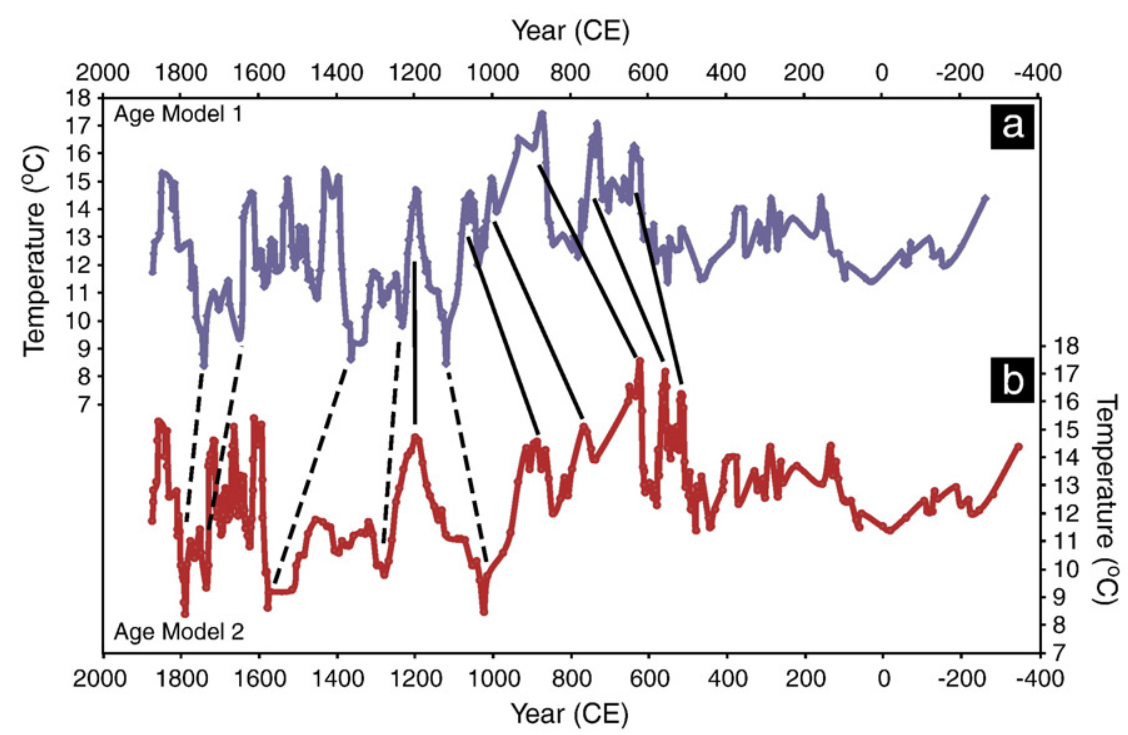

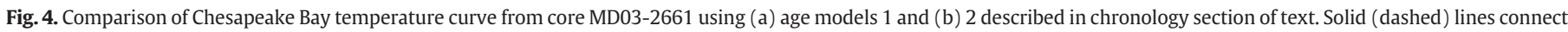

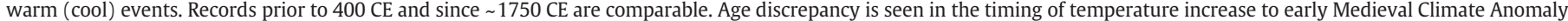

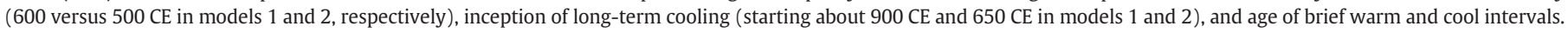
See text.

$\mathrm{CaCO}_{3}$ shells (foraminifera and mollusks) and bulk sediment, which allow the following conclusions regarding the bay's sediment chronology. 1) A standard 400 year marine reservoir correction applies to accelerator mass spectrometer (AMS) radiocarbon dates on biogenic carbonate (mollusks and foraminifers) based on radiocarbon dates on mollusks from 19th century museum collections and from sediments deposited during colonial land clearance dated by pollen stratigraphy. 2) Porewater dissolved organic carbon does not influence biogenic carbonate dates (Colman et al., 2002). 3) Holocene radiocarbon dates on pollen and bulk organic carbon are systematically older by $1500-$ 2000 years than dates on shell from the same sample, probably due to transport of pollen organic carbon. 4) ${ }^{137} \mathrm{Cs}$ and ${ }^{210} \mathrm{~Pb}$ dating and pollen stratigraphy tied to colonial land clearance yield consistent ages for sediment deposited during the last 50 to 300 years. 5) Bioturbation, burrowing, and reworking are minimal in cores recovered from the main channel of Chesapeake Bay, such as those discussed here, where the thickest accumulation of Holocene sediment is found at water depths of 10-35 m.

The major limiting factors for Holocene chronology in $\mathrm{CB}$ are age uncertainty for calibrated radiocarbon ages and changes in sedimentation rates at some sites. Fig. 3 presents the age-depth plots for the two long records MD03-2661 and RD-2209; Table 2 lists radiocarbon ages and pollen data used for dating MD03-2661 from Cronin et al. (2007). In MD03-2661, two pollen horizons and 11 radiocarbon dates were used to

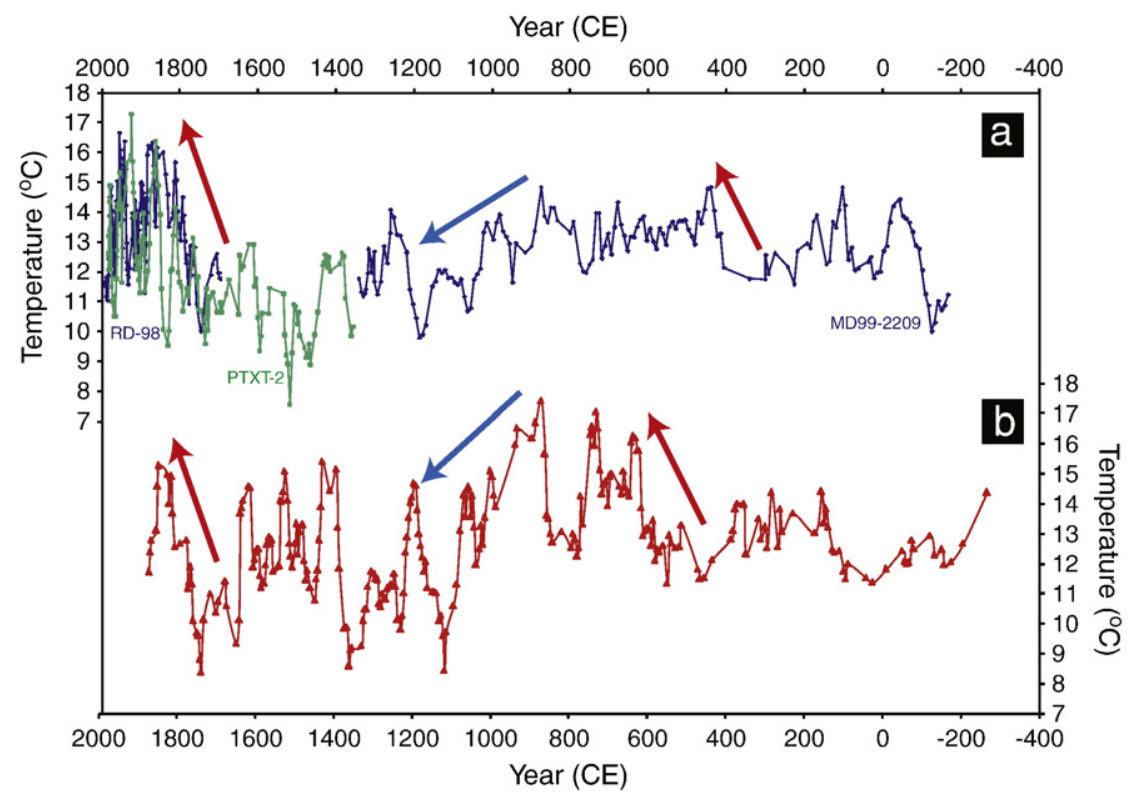

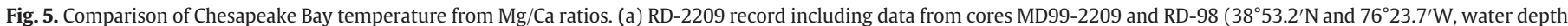

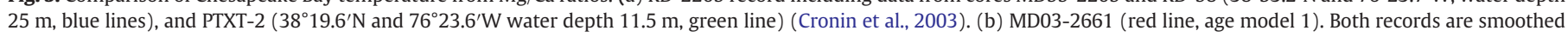

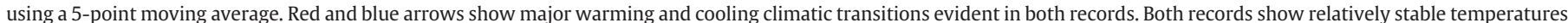

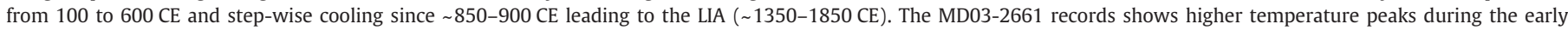

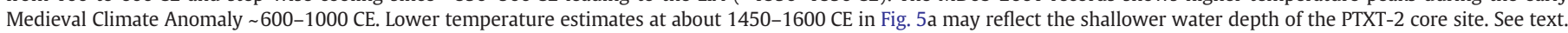
(For interpretation of the references to color in this figure legend, the reader is referred to the web version of this article.) 


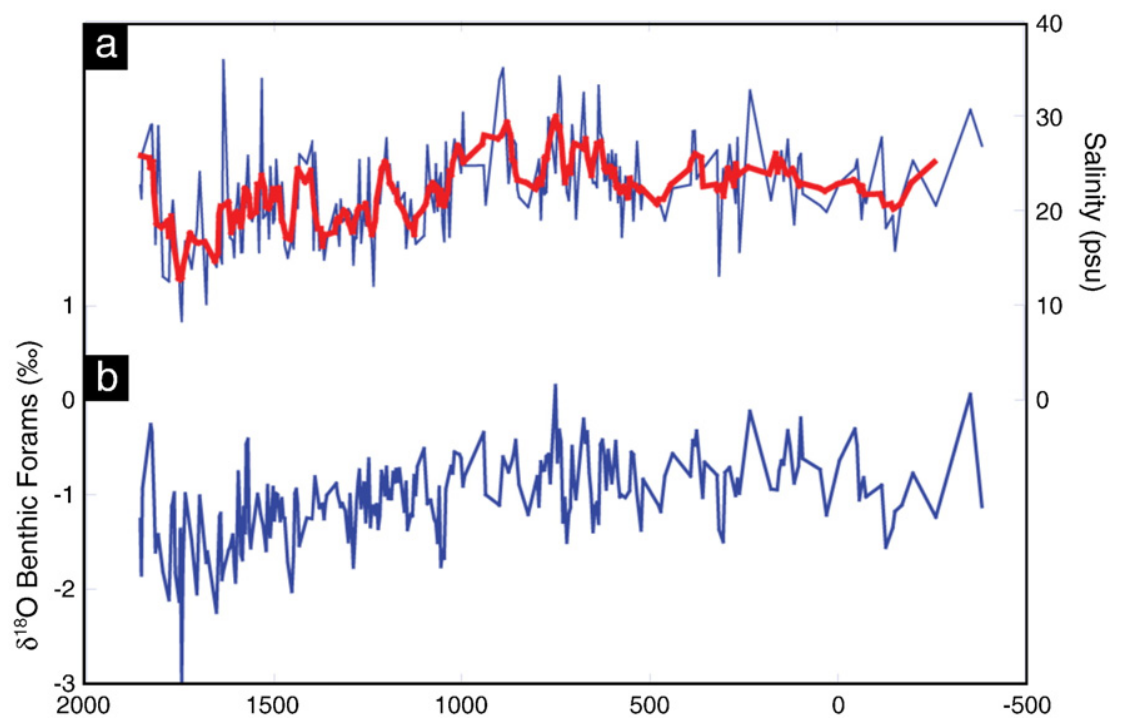

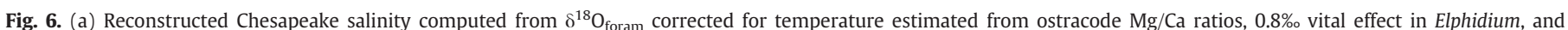

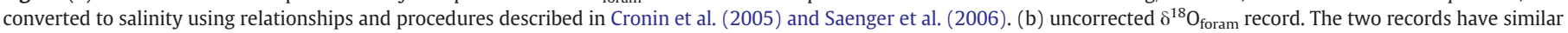
first-order temporal patterns suggesting $\delta^{18} \mathrm{O}_{\text {foram }}$ values reflect mainly hydrographic changes rather than water temperature.

date the upper $1000 \mathrm{~cm}$ of the core covering the last 2600 years (Fig. 3a). The pollen horizon at $155 \mathrm{~cm}$ core depth is the first regular occurrence of ragweed pollen, a marker in CB sediments for early colonial land clearance dated at about 1725 CE (Willard et al., 2003). MD03-2661 did not recover the well-known ragweed peak when ragweed pollen reached $10-15 \%$ of the total pollen assemblage during maximum land clearance in the late 19th century. Consequently, sediment deposited during the last century was not recovered at this site, most likely due to the coring procedure, and we estimate the age of the coretop to be roughly 1880-1885 CE. The radiocarbon dates from MD03-2661 were obtained on well-preserved shells of the bivalve Mulinia lateralis and calibrated using the CALIB (Stuiver et al., 1998). The mean $2 \sigma$ age range on nine calibrated $M$. lateralis dates from MD03-2661 for the last 2600 years is 178 years.

Two age models were developed for MD03-2661. Age model 1 (AM1) assumes a near constant sedimentation rate and estimates

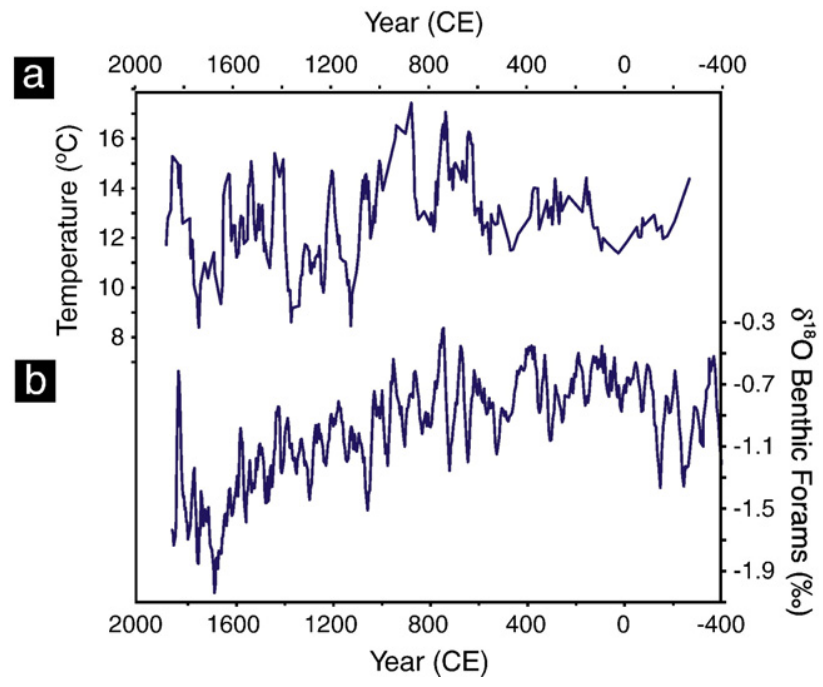

Fig. 7. Late Holocene Chesapeake Bay. (a) Temperature from $\mathrm{Mg} / \mathrm{Ca}$ ratios of ostracodes (Loxoconcha matagordensis) and (b) $\delta^{18} \mathrm{O}_{\text {foram }}$ from benthic foraminifera (Elphidium selseyense) for upper $1000 \mathrm{~cm}$ of core MD03-2661 (5-point smoothing). More negative (positive) $\delta^{18} \mathrm{O}_{\text {foram }}$ excursions signify enhanced (reduced) river runoff and precipitation; dry periods marked by red circles. (For interpretation of the references to color in this figure legend, the reader is referred to the web version of this article.) sample ages from core depth as follows: $\left(0.0008 * \operatorname{depth}^{2}\right)-$ $(1.5417 *$ depth $)+1884.3\left(\mathrm{r}^{2}=0.981\right.$, mean rate $\left.\sim 0.41 \mathrm{~cm} \mathrm{yr}^{-1}\right)$. A second age model (AM2) was developed to reflect apparent changes in sedimentation rate seen in the age-depth plot, with higher rates at core depths from 0 to $300 \mathrm{~cm}$ and 485 to $713 \mathrm{~cm}$ and lower rates from 300 to $485 \mathrm{~cm}$ and 713 to $1087 \mathrm{~cm}$. Linear sedimentation rates were computed for four segments of the core as follows: $0-300 \mathrm{~cm}-$ $0.96 \mathrm{~cm} \mathrm{yr}^{-1}, 300-485 \mathrm{~cm}-0.2 \mathrm{~cm} \mathrm{yr}^{-1}, 485-713 \mathrm{~cm}-0.91 \mathrm{~cm} \mathrm{yr}^{-1}$ and $713-1087 \mathrm{~cm}-0.3 \mathrm{~cm} \mathrm{yr}^{-1}$.

Fig. 3b shows 10 radiocarbon dates on $M$. lateralis from the upper $800 \mathrm{~cm}$ at site RD-2209. Sediment at this site was deposited at a near constant rate of $0.36 \mathrm{~cm} \mathrm{yr}^{-1}$ during the last 2100 years and includes a 20th century sediment record. Sample ages for RD-2209 were estimated using the age model described fully in Willard et al. (2003). A zone of slow sedimentation or intermittent non-deposition occurs at $800-900 \mathrm{~cm}$ core depth estimated to represent the interval about 2100-5000 calibrated years age (Colman et al., 2002).

\section{Results}

Fig. 4 compares the MD03-2661 Mg/Ca-derived temperature curves using the two age models. Both age models show relatively cool to moderate temperatures $\left(12-14{ }^{\circ} \mathrm{C}\right)$ from $300 \mathrm{BCE}$ to $400 \mathrm{CE}$ and a steep rise in temperature starting around $1750-1800 \mathrm{CE}$. Several temperature maxima $\left(\geq 15^{\circ} \mathrm{C}\right)$ and minima $\left(\leq 10{ }^{\circ} \mathrm{C}\right)$ have age differences from the two age models ranging from $<100$ years up to $\sim 250$ years. For example, a distinct temperature maximum is dated in both age models at around $1200 \mathrm{CE}$, whereas the preceding cool interval is dated at 1000 to $1100 \mathrm{CE}$. The warmest period in this core occurs during the early MCA, dated at about 850-900 in AM1 and 600-650 in AM2, after which there is step-wise cooling. The difference between the two age models for the youngest LIA temperature minimum is less than 100 years $(1750-1800 \mathrm{CE})$.

Fig. 5 compares the MD03-2661 (AM1) and RD-2209 temperature curves designating those parts of the latter curve derived from the RD-98, PTXT-2 and MD99-2209 cores. Both records show the following features: multidecadal scale oscillations over a total temperature range from $\sim 8$ to $17^{\circ} \mathrm{C}$, moderate temperatures $\left(12-14^{\circ} \mathrm{C}\right.$ ) from $\sim 100 \mathrm{BCE}$ to $400 \mathrm{CE}$, a steep rise in temperature beginning about 1750-1800 CE, a cooling 750-850 CE, a step-wise decline starting 850-950 CE, and multiple temperature minima between 1100 and 1750 CE. Temperature maxima during the early MCA (400-1050 CE) 


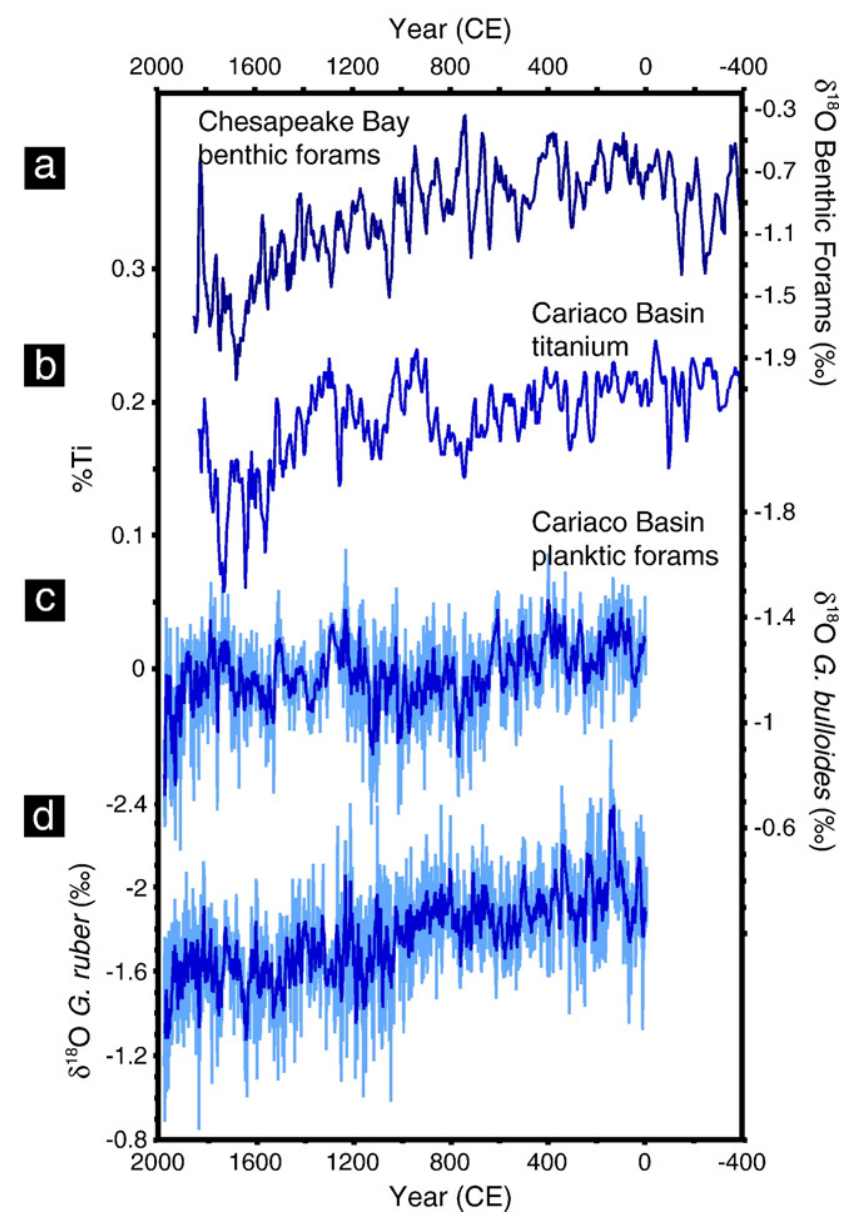

Fig. 8. (a) $\delta^{18} \mathrm{O}_{\text {foram }}$ from benthic foraminifera (Elphidium selseyense) for upper $1000 \mathrm{~cm}$ of core MD03-2661 $\left(38^{\circ} 53.21^{\prime} \mathrm{N}\right.$ and $76^{\circ} 23.89^{\prime} \mathrm{W}$, water depth $25 \mathrm{~m}$ ) (5-point smoothing). (b) Cariaco Basin sedimentary\% titanium (Haug et al., 2001, 3-point smooth). (c) and (d) Cariaco Basin $\delta^{18} \mathrm{O}$ of the planktic foraminifers Globigerina bulloides and G. ruber (Black et al., 2004), dark blue is 5-point smooth. (For interpretation of the references to color in this figure legend, the reader is referred to the web version of this article.)

are slightly cooler $\left(2-3{ }^{\circ} \mathrm{C}\right)$ in MD99-2209 than those in the MD03-2661 curve. Large temperature oscillations $\left(>5^{\circ} \mathrm{C}\right.$ ) between 1350 and $1750 \mathrm{CE}$ are also greater in MD03-2661, but this may reflect the shallower water depth for site PTXT-2 (12 m) versus MD03-2661 (25 m). The step-wise cooling beginning 850-900 CE reached minimum temperatures about $1150-1200$ CE that are slightly cooler in MD03-2661. Three brief but distinct warm intervals can be correlated in the two curves centered on 1200,1400, and 1630 CE. A fourth warm interval is seen near 1500 CE in MD03-2661, but this is not so evident in RD-2209.

There are several periods of cool temperatures during the Little Ice Age. For example, temperature estimates for the PTXT-2 record reached $9.5^{\circ} \mathrm{C}$ several times between $\sim 1450$ and $1830 \mathrm{CE}$ and the MD03-2661 record reached $8.3-11{ }^{\circ} \mathrm{C}$ from 1360 to $1750 \mathrm{CE}$. The cool period from 1700 to $1750 \mathrm{CE}$ is recorded in all three cores and seems to coincide with widespread LIA cooling during the Maunder solar minimum (see below). In summary, the two temperature records are broadly similar, but the MD03-2661 curve indicates a slightly warmer early MCA, higher temperatures during warming events at $\sim 1200$ and $1400 \mathrm{CE}$ during the late MCA, and lower temperatures $\left(1-2{ }^{\circ} \mathrm{C}\right)$ during the coolest part of the LIA 1650-1750 CE.

The MD03-2661 $\delta^{18} \mathrm{O}_{\text {foram }}$ values (corrected for vital effects and temperature) and estimated $\delta^{18} \mathrm{O}_{\text {baywater values using AM1 are shown }}$ in Fig. 6. The $\mathrm{CB} \delta^{18} \mathrm{O}_{\text {foram }}$ data indicates moderately high salinity and dry conditions ( $\delta^{18} \mathrm{O}_{\text {foram }}$ maxima) from $200 \mathrm{BCE}$ to $300 \mathrm{CE}$, and several brief dry periods between 600 and $1200 \mathrm{CE}$. These would be 1-2 centuries older using age model AM2. The highest $\delta^{18} \mathrm{O}_{\text {foram }}$ values and estimated salinities (25-30) are seen between 500 and $1000 \mathrm{CE}$ suggesting reduced freshwater influx and periods of drier regional climate. The $\delta^{18} \mathrm{O}_{\text {foram }}$ values progressively decrease after 1000 CE (650-700 CE in AM2) culminating in minimum values of -2.0 to $-2.25 \%$ and minimum salinities (16-18) around 1650 $1800 \mathrm{CE}$, reflecting a wetter regional climate during the LIA.

Comparison of the MD03-2661 temperature and $\delta^{18} \mathrm{O}_{\text {foram }}$ records indicates that, over centennial timescales, relatively warm bay temperatures generally correspond to enriched $\delta^{18} \mathrm{O}_{\text {foram }}$ and cool temperatures correspond to depleted values (Fig. 7). This pattern would suggest alternating warm-dry and cool-wet conditions in the mid-Atlantic region. Both records suggest a complex, step-wise climatic transition from the MCA to the LIA that is characterized by multidecadal fluctuations in temperature and rainfall. The emergence from Little Ice Age conditions seen in both rising temperature and decreasing precipitation is abrupt and nearly synchronous.

\subsection{Comparison with precipitation records}

We compare the $\mathrm{CB} \delta{ }^{18} \mathrm{O}$ record with both the titanium (Ti) and planktic foraminiferal oxygen isotopes records from Cariaco Basin sediments in the Caribbean in Fig. 8. The Cariaco Basin records are considered to be proxies of variability in the position of the Intertropical Convergence Zone (ITCZ) and hence tropical rainfall (Fig. 8). The general shape of the Cariaco \%Ti record (Haug et al., 2001) (Fig. 8b) resembles that for MD03-2661 $\delta^{18} \mathrm{O}_{\text {foram }}$ variability (Fig. 8a), but the two curves are opposite in sign. That is, drier mid-latitudes (higher $\mathrm{CB} \delta^{18} \mathrm{O}$ values) correspond to wetter tropical regions (higher titanium concentrations). The Cariaco planktic foraminiferal $\delta^{18} \mathrm{O}$ curves of Black et al. (2004) (Fig. 8c and d) also suggest multidecadal and centennial variability in Caribbean climate. The long-term increase in $G$. ruber $\delta^{18} \mathrm{O}$ was interpreted by Black as signifying either a cooling of tropical summer-fall SSTs of as much as $2{ }^{\circ} \mathrm{C}$, perhaps related to an increase in upwelling intensity, or regional evaporation/ precipitation variability due to changes in the mean annual position of the ITCZ (see also Tedesco and Thunell, 2003). The former would be consistent with evidence for a cooler Little Ice Age and the former with the Cariaco titanium and CB isotopic records of hydrological variability. Other low-latitude Atlantic hydrologic records support the idea that late Holocene ITCZ variability was an important driver of late Holocene hydrological variability in the Caribbean and subtropical North Atlantic (e.g. Hodell et al., 2005; Lund and Curry, 2006).

It is also noteworthy that continental-scale droughts during the medieval period have been documented in tree-ring records from North America covering the last 1000 years (Cook et al., 2007). Although age uncertainty and temporal resolution preclude a direct correlation of the $\mathrm{CB}$ sediment record with annually-resolved tree-ring records, several positive $\delta^{18} \mathrm{O}_{\text {foram }}$ excursions in Fig. 8 nonetheless coincide with continental-scale megadroughts centered at 936, 1034, 1150, 1253, and $1370 \mathrm{CE}$.

\subsection{North Atlantic Ocean Temperature}

To investigate SST variability across the North Atlantic, we combined the MD03-2661 (AM1) and RD-2209 records to produce a composite SST reconstruction covering the last 2200 years (Fig. 9a). This composite record is compared with temperature reconstructions from the Cariaco Basin (Black et al., 2004), the Laurentian slope upper North Atlantic Deep Water (NADW) (Marchitto and deMenocal, 2003), off northern Iceland (Sicre et al., 2008), the VØring Plateau (Andersson et al., 2003), and a northern hemisphere composite temperature curve (Moberg et al., 2005) (Fig. 9b-f). In addition to the $\mathrm{CB} \mathrm{Mg} / \mathrm{Ca}$ curve, the Iceland and VØring records are considered 


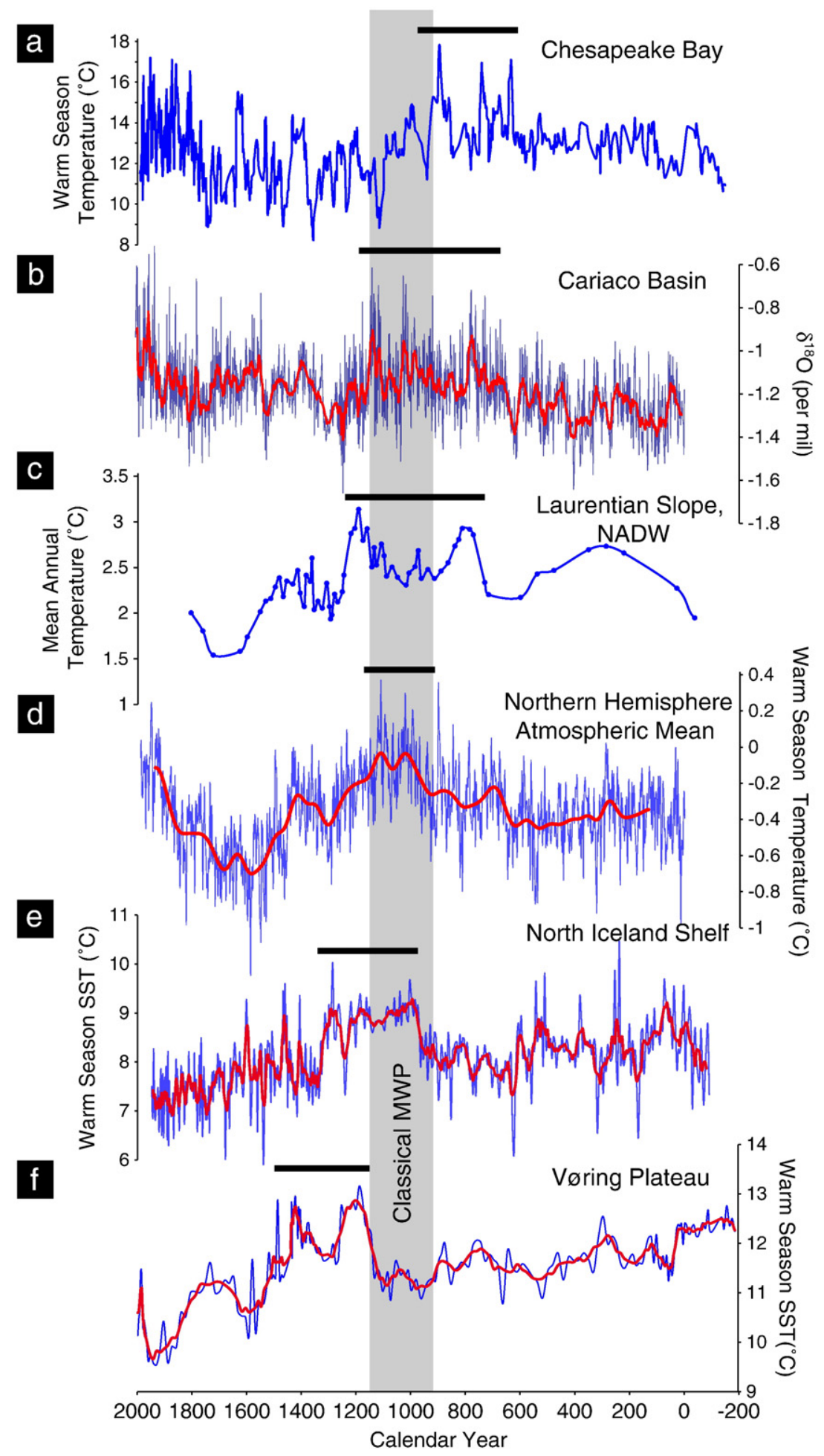

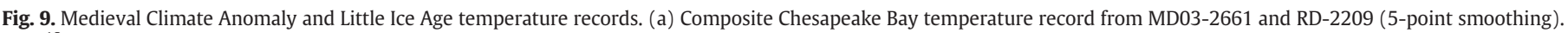

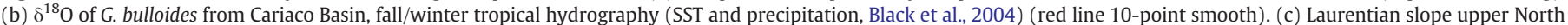

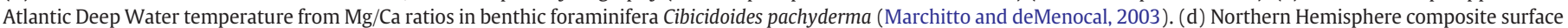

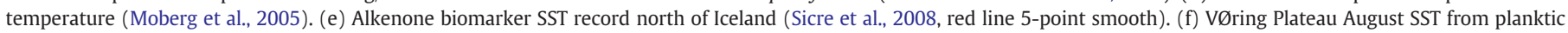

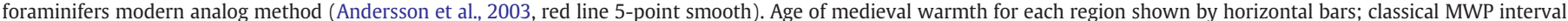

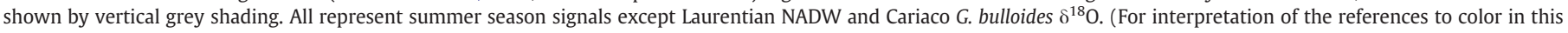
figure legend, the reader is referred to the web version of this article.)

representative of warm-season temperature, the Laurentian record is mean annual upper NADW temperature, the Moberg curve represents mean annual atmospheric temperature, and the G. ruber $\delta^{18} \mathrm{O}$ Cariaco record either surface ocean temperature, upwelling and/or evaporation/precipitation.
One notable feature in Fig. 9 is that the amplitude of regional ocean temperature variability during the last two millennia was large ( $\sim 2$ to $\left.>4{ }^{\circ} \mathrm{C}\right)$ relative to that of mean atmospheric temperature $\left(\sim 0.5^{\circ} \mathrm{C}\right)$. High amplitude regional SST variability would be expected based on the western North Atlantic ICOADS record (Fig. 2), as well as basin-wide 


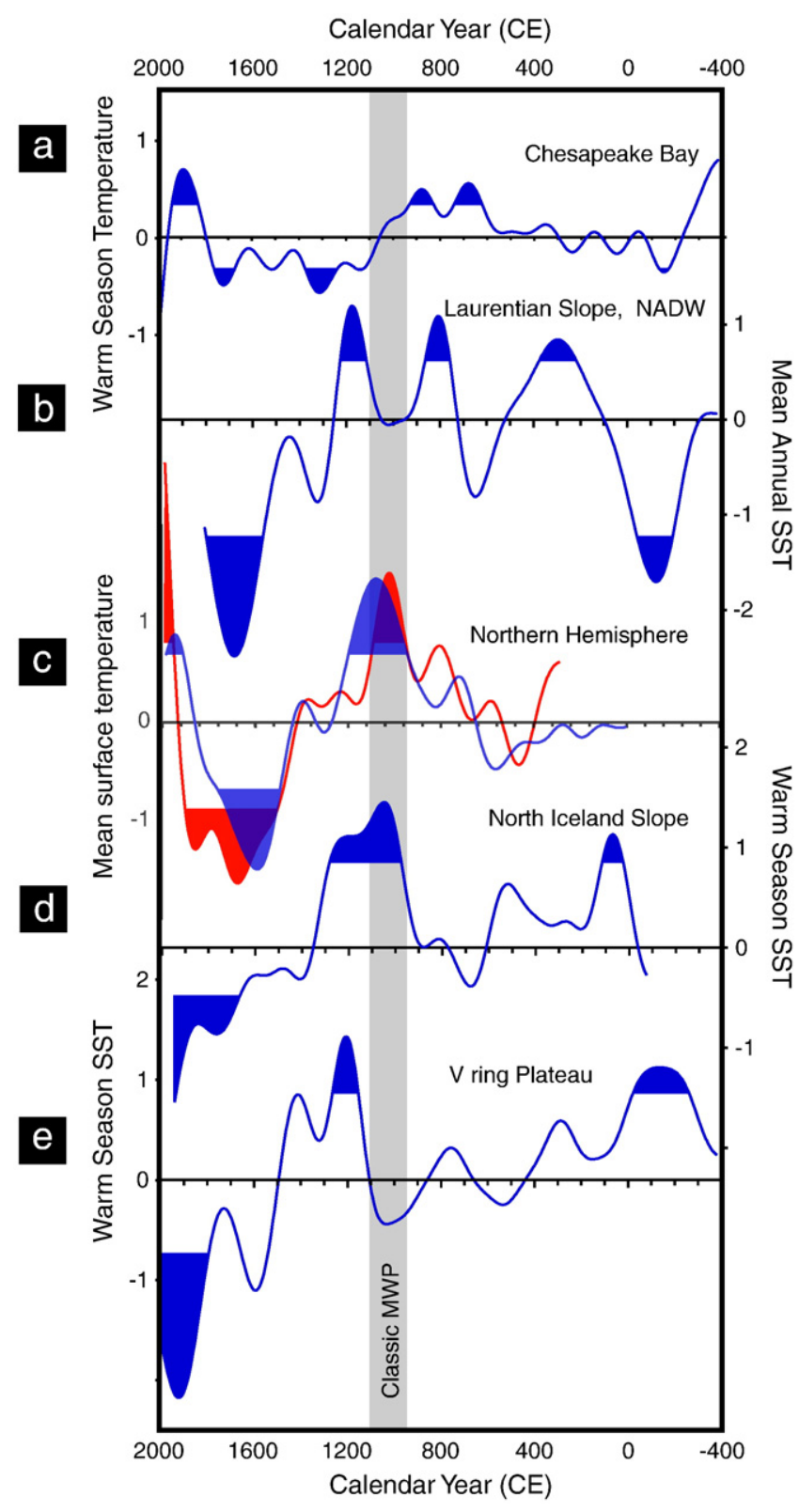

Fig. 10. Comparison of 200-year butterworth low-pass filtered standardized temperature anomalies (anomaly of timeseries divided by its standard deviation). (a) Composite Chesapeake Bay temperature record. (b) Laurentian Slope upper North Atlantic Deep Water temperature from benthic foraminifera (Cibicidoides pachyderma $\mathrm{Mg} / \mathrm{Ca}$ ratios (Marchitto and deMenocal, 2003). (c) Northern Hemisphere surface temperature (Moberg et al., 2005, blue; Mann et al., 2008, red). (d) subpolar North Atlantic SST from alkenone biomarkers, north Iceland Slope (Sicre et al., 2008). (e) Vøring Plateau August SST from modern analog method of planktic foraminifers (Andersson et al., 2003). Anomalous warm and cool periods falling outside $1 \sigma$ of the mean are filled. The classical MWP (950-1100 CE) is shaded. (For interpretation of the references to color in this figure legend, the reader is referred to the web version of this article.)

decadal patterns in instrumental records of North Atlantic SST (e.g. Deser and Blackmon, 1993; Enfield et al., 2001).

A second obvious feature in the comparison of temperature records is that the timing of peak regional warmth for the last 2000 years, shown by horizontal black bars, does not always coincide with the classic Medieval Warm Period centered on 1000-1050 CE. CB was warmest in the few centuries before the MWP, the VØring Plateau the two centuries after, the Laurentian Slope the century before and the century after, and the North Iceland Shelf during and just after the MWP. All records show a cool interval during all or part of the LIA
1600-1800 CE, although cool intervals also occurred in CB and the Laurentian Slope prior to this time and persisted after the LIA in the VØring and N. Iceland Shelf regions.

To further evaluate low frequency SST variability, composite curves of low-pass filtered temperature anomalies (Fig. 10) show that warm CB SSTs between 600 and 1000 CE (Fig. 10a) overlap with the latter part of what is sometimes called the cool "Dark Ages" in Europe, predating the classical Medieval Warm Period seen in atmospheric temperature curves of Moberg et al. (2005) and Mann et al. (2008) (Fig. 10c). The Laurentian Slope temperature record shows similarities to the $\mathrm{CB}$ record with a maximum near $800 \mathrm{CE}$ (Fig. 10b), which is consistent with evidence for warm SSTs over the Laurentian Fan from 500 to 900 CE (Keigwin and Pickart, 1999) and in the Gulf of Mexico 600 to 1000 CE (Richey et al., 2007). In contrast, a second deep-water temperature maximum near $1200 \mathrm{CE}$ coincides with cool CB temperature before the onset of a $2{ }^{\circ} \mathrm{C}$ LIA cooling on the Laurentian slope. SSTs on the North Iceland Shelf are cool during the early MCA, but reach a peak between 1000 and $1300 \mathrm{CE}$, which overlaps in part with the classic MWP (Fig. 10d). In contrast to sites in the western North Atlantic, the VØring Plateau was relatively cool during most of this interval, until a $\sim 2{ }^{\circ} \mathrm{C}$ temperature rise began about 1200 CE (Fig. 10e).

\section{Discussion}

Our results for the Chesapeake Bay together with those mentioned above shed light on patterns of low frequency hemisphere-scale climate variability of the last 2000 years (Figs. 9 and 10). Ocean temperature variability during the MCA and LIA exhibited complex spatial and temporal patterns with maximum ocean temperatures occurring at different times between 600 and 1400 CE across the North Atlantic. In particular, warm surface water conditions occurred before the classic MWP in the western North Atlantic, and during or after the MWP in northeastern regions. Likewise, deep waters in the North Atlantic warmed both before and after the MWP. In addition, the inception of cooling that culminated in the LIA began earlier in the western North Atlantic (Chesapeake) than in eastern regions (Nordic Seas). Such spatial variability has also been observed in terrestrial temperature records from tree rings (D'Arrigo et al., 2006) and in ocean records near Iceland, Norway, Scotland and the Iberian Peninsula (Eiríksson et al., 2006).

A related issue pertains to the causes of Holocene climate variability in the North Atlantic region. It has been proposed that the MCA-LIA interval was the most recent in a series of near-synchronous, solar-driven, 1500-year Holocene climate oscillations recognized in subpolar ice-rafted debris (IRD) records (e.g., Bond et al., 2001). Similarly, Chinese speleothem isotope records showing six Holocene shifts in the intensity of the East Asian Monsoon that are correlative with the North Atlantic IRD pulses, implying a common forcing mechanism such as solar irradiance (Wang et al., 2005). Although solar-forcing cannot be ruled out as a triggering mechanism, the SST variability discussed above was not synchronous across the North Atlantic for the MCA-LIA interval. In fact, west-to-east "provincialism" in North Atlantic climate has been observed over several timescales: in Holocene millennial-scale sea-ice and surface salinity (de Vernal and Hillaire-Marcel, 2006) and SST in the North Atlantic (Keigwin and Pickart, 1999; deMenocal et al., 2000), 20th century decadal sea-ice fluctuations (Deser et al., 2000), and SST and deep water formation during the last few decades (Dickson et al., 2002). The temperature patterns presented above thus support paleoceanographic evidence (Newton et al., 2006) and model simulations (Renssen et al., 2006, 2007; Saenger et al., 2009) that suggest coupled oceanic-atmospheric processes, possibly involving deep-water formation in subpolar regions, may have influenced regional climate during the MCA-LIA. Although our emphasis has been on low frequency variability, the $\sim 28$ brief warm periods seen in the 2200 -yr Mg/Ca-derived temperature 
curve (Fig. 9) suggest changes in Chesapeake source water emanating in the Mid-Atlantic Bight, the Labrador Sea and farther north about every 75-80 years. This is roughly equivalent to the timing of seasurface temperature variability associated with the Atlantic Multidecadal Oscillation. Such a conclusion is also supported by modeling studies showing that internal Atlantic Ocean variability produces multidecadal oscillations that can significantly influence mean Northern Hemisphere surface temperatures (Zhang et al., 2007).

Although our study was limited to the North Atlantic region, it illustrates how large-scale regional climate variability can be lost or subdued in hemisphere-scale compilations of mean annual surface temperature. It also highlights the need for many additional highresolution ocean records, especially in the subpolar North Atlantic, for a more complete understanding of late Holocene climate dynamics.

\section{Acknowledgements}

We are grateful to C. Laj, Y. Balut, and the captain and crew of Marion-Dufresne, S. Worlsey for ICOADS data, D. Black, T. Marchitto, and J. Sachs for input on Holocene ocean records, and H. Dowsett, J. McGeehin and three anonymous reviewers for comments. We thank E. Tappa, S. Smith, M. Berke, M. Yasuhara, and J. Farmer for lab and manuscript assistance. We thank the support from the USGS Global Change Program.

\section{References}

Ammann, C.M., Joos, F., Schimel, D.S., Otto-Bliesner, B., Tomas, R.A., 2007. Solar influence on climate during the past millennium: results from transient simulations with the NCAR Climate System Model. Proceedings National Academy of Sciences 104 3713-3718.

Andersson, C. Risebrobakken, B., Jansen, E., Dahl, S.O., 2003. Late Holocene surface ocean conditions of the Norwegian Sea (Vøring Plateau). Paleoceanography 18 1044. doi:10.1029/2001PA000654

Black, D.E., Thunell, R.C., Kaplan, A., Peterson, L.C., Tappa, E.J., 2004. A 2000-year record of Caribbean and tropical North Atlantic hydrographic variability. Paleoceanography 19, PA2022. doi:10.1029/2003PA000982.

Boicourt, W.C., Kuzmic, M., Hopkins, T.S., 1999. The inland sea: circulation of Chesapeake Bay and the northern Adriatic. In: Malone, T.C., et al. (Ed.), Ecosystems at the Land-Sea Margin: AGU Coastal and Estuarine Studies no. 55, Washington, D.C., pp. 81-129.

Bond, G., Kromer, B., Beer, J., Muscheler, R., et al., 2001. Persistent solar influence on North Atlantic Climate during the Holocene. Science 294, 2130-2136.

Bratton, J.F., Colman, S.M., Seal II, R.R., 2003. Eutrophication and carbon sources in Chesapeake Bay over the last $2700 \mathrm{yr}$ : human impacts in context. Geochimica Cosmochimica Acta 67, 3385-3402.

Broecker, W.S., 2001. Was the Medieval Warm Period global? Science 291, 1497-1499.

Brush, G.S., 1989. Rates and patterns of estuarine sediment accumulation. Limnology and Oceanography $34,1235-1246$

Chapman, D.C., Beardsley, R.C., 1989. On the origin of shelf water in the Middle Atlantic Bight. Journal Physical Oceanography 19, 384-391.

Colman, S.M., Bratton, J.F., 2003. Anthropogenically induced changes in sediment and biogenic silica fluxes in Chesapeake Bay. Geology 31, 71-74

Colman, S.M. Baucom, P.C, Bratton, J., Cronin, T.M., McGeehin, J.P. Willard, D.A Zimmerman, A., Vogt, P.R., 2002. Radiocarbon dating of Holocene sediments in Chesapeake Bay. Quaternary Research 57, 58-70.

Cook, E.R., Seager, R., Cane, M.A., Stahle, D.H., 2007. North American drought: reconstructions causes and consequences. Earth-Science Reviews 81, 93-134.

Cronin, T.M. (Ed.), 2000. Initial Report on IMAGES V Cruise of Marion-Dufresne to Chesapeake Bay June, 1999, US Geological Survey Open-file Report 00-306.

Cronin, T.M., Willard, D.A., Kerhin, R.T, Karlsen, A, Holmes, C. Ishman, S, Verardo, S. McGeehin, J., Zimmerman, A., 2000. Climatic variability over the last millennium from the Chesapeake Bay sedimentary record. Geology 28, 3-6.

Cronin, T.M., Dwyer, G.S., Kamiya, T., Schwede, S., Willard, D.A., 2003. Medieval Warm Period, Little Ice Age and 20th century temperature variability from Chesapeake Bay. Global and Planetary Change 36, 17-29.

Cronin, T.M., Thunell, R., Dwyer, G.S., Saenger, C., Mann, M.E., Vann, C., Seal II, R.R., 2005 Multiproxy evidence of Holocene climate variability from estuarine sediments, eastern North America. Paleoceanography 20, PA4006. doi:10.1029/2005PA001145.

Cronin, T.M., Vogt, P.R., Willard, D.A., Thunell, R., Halka, J., Berke, M., Pohlman, J., 2007. Rapid sea level rise and ice sheet response to 8, 200-year climate event. Geophysical Research Letters 34, L20603.

Crowley, T.J., 2000. Causes of climate change over the past 1000 years. Science 289 $270-277$

D'Arrigo, R., Wilson, R., Jacoby, G., 2006. On the long-term context for late twentieth century warming. Journal of Geophysical. Research 111, D03103. doi:10.1029/2005JD006352. de Vernal, A., Hillaire-Marcel, C., 2006. Provincialism in trends and high frequency changes in the northwest North Atlantic during the Holocene. Global and Planetary Change 54, 263-290.

deMenocal, P.B., Ortiz, J., Guilderson, T., Sarnthein, M., 2000. Coherent high- and lowlatitude climate variability during the Holocene Warm Period. Science 288 2198-2202.

Deser, C., Blackmon, M.L., 1993. Surface climate variations over the North Atlantic Ocean during winter: 1900-1989. Journal of Climate 6, 1743-1753.

Deser, C., Walsh, J.E., Timlin, M.S., 2000. Arctic sea ice variability in the context of recent atmospheric circulation trends. Journal of Climate 13, 617-633.

Dickson, R.R., Yashayaev, I., Meincke, J., Turrell, W., Dye, S., Holfort, J., 2002. Rapid freshening of the deep North Atlantic over the past four decades. Nature 416, 832-837.

Dwyer, G.S., Cronin, T.M., Baker, P.A., 2002. Trace elements in marine ostracodes. In: Holmes, J.A., Chivas, A.R. (Eds.), American Geophysical Union Monograph 131: The Ostracoda: Applications in Quaternary Research, pp. 205-225.

Edwards, A., 2007. Holocene molluscan aminochronology and time averaging in Chesapeake Bay sediments. Masters Thesis. University of Delaware.

Eiríksson, J., Bartels-Jónsdóttir, H.B., Cage, A.G., Gudmundsdóttir, E.R., KlitgaardKristensen, D., Marret, F., Rodrigues, T., Abrantes, F., Austin, W.E.N., Jiang, H., Knudsen, K.-L., Sejrup, H.-P., 2006. Variability of the North Atlantic Current during the last 2000 years based on shelf bottom water and sea surface temperatures along an open ocean/shallow marine transect in western Europe. The Holocene 16, 1017-1029.

Enfield, D.B., Mestas-Nunez, A.M., Trimble, P.J., 2001. The Atlantic Multidecadal Oscillation and its relationship to rainfall and river flows in the continental U.S. Geophysical Research Letters 28, 2077-2080. doi:10.1029/2000GL012745.

Gibson, J.R., Najjar, R.G., 2000. The response of Chesapeake Bay salinity to climateinduced changes in streamflow. Limnology and Oceanography 45, 1764-1772.

Goosse, H., Arzel, O., Luterbacher, J., Mann, M.E., Renssen, H., Riedwyl, N., Timmermann, A., Xoplaki, E., Wanner, H., 2006. The origin of the European "Medieval Warm Period". Climate of the Past 2, 99-113.

Haug, G.H., Hughen, K.A., Peterson, L.C., Sigman, D.M., Röhl, U., 2001. Southward migration of the Intertropical Convergence Zone through the Holocene. Science 293, 1304-1308.

Hodell, D.A., Brenner, M., Curtis, J.H., 2005. Terminal Classic drought in the northern Maya lowlands inferred from multiple sediment cores in Lake Chichancanab (Mexico). Quaternary Science Reviews 24, 1413-1427.

Houghton, R.W., Fairbanks, R.G., 2001. Water sources for Georges Bank. Deep-Sea Research II 48, 95-114.

Jones, P.D., Mann, M.E., 2004. Climate over past millennia. Reviews of Geophysics 42, RG2002. doi:10.1029/2003RG000143.

Karlsen, A.W. Cronin, T.M. Ishman, S.E., Willard, D.A., Holmes, C., Marot, M., Kerhin, R. 2000. Historical trends in Chesapeake Bay dissolved oxygen based on benthic foraminifera from sediment cores. Estuaries 23, 488-508.

Keigwin, L.D., Pickart, R.S., 1999. Slope water current over the Laurentian Fan on interannual to millennial time scales. Science 286, 520-523.

Kerhin, R.T., Williams, C., Cronin, T.M., 1998. Lithologic descriptions of piston cores from Chesapeake Bay, Maryland: US Geological Survey Open-file Report 98-787.

Lund, D.C., Curry, W., 2006. Florida current surface temperature and salinity variability during the last millennium. Paleoceanography 21, PA2009. doi:10.1029/2005PA001218.

Mann, M.E., Jones, P.D., 2003. Global surface temperatures over the past two millennia. Geophysical Research Letters 30, 1820. doi:10.1029/2003GL017814.

Mann, M.E., Zhang, Z., Hughes, M.K., Bradley, R.S., Miller, Sonya K., Rutherford, S., Fenbiao Ni, F., 2008. Proxy-based reconstructions of hemispheric and global surface temperature variations over the past two millennia. Proceedings National Academy of Sciences 105, 13252-13257.

Mann, M.E., Zhang, Z., Rutherford, S., Bradley, R.S., Hughes, M.K., Shindell, D., Ammann, C., Faluvegi, G., Ni, F., 2009. Global signatures and dynamical origins of the Little Ice Age and Medieval Climate Anomaly. Science 326, 1256-1260.

Marchitto, T.M., deMenocal, P.B., 2003. Late Holocene variability of upper North Atlantic Deep Water temperature and salinity. Geochemistry, Geophysics, Geosystems 1100. doi:10.1029/2003GC000598.

Moberg, A., Sonechkin, D.M., Holmgren, K., Datsenko, N.M., Karlén, W., 2005. Highly variable northern hemisphere temperatures from low- and high-resolution proxy data. Nature 433, 613-617.

Newton, A., Thunell, R., Stott, L., 2006. Climate and hydrographic variability in the Indo-Pacific Warm Pool during the last millennium. Geophysical Research Letters 33, L19710. doi:10.1029/2006GL027234.

Oppo, D.W., Rosenthal, Y., Linsley, B.K., 2009. 2, 000-year-long temperature and hydrology reconstructions from the Indo-Pacific warm pool. Nature 460,1113-1116.

Petrie, B., Drinkwater, K., 1993. Temperature and salinity variability on the Scotian Shelf and in the Gulf of Maine 1945-1990. Journal of Geophysical Research 98 (C11), 20079-20089.

Renssen, H., Goosse, H., Muscheler, R., 2006. Coupled climate model simulation of Holocene cooling events: oceanic feedback amplifies solar forcing. Climate of the Past 2, 79-90.

Renssen, H., Goosse, H., Fichefet, T., 2007. Simulation of Holocene cooling events in a coupled climate model. Quaternary Science Reviews 26, 2019-2029.

Richey, J.N., Poore, R.Z., Flower, B.P., Quinn, T.M., 2007. 1400 yr multiproxy record of climate variability from the northern Gulf of Mexico. Geology 35, 423-426.

Ruddiman, W.F., 2007. The early anthropogenic hypothesis: challenges and responses. Reviews of Geophysics 45, RG4001. doi:10.1029/2006RG000207.

Saenger, C., Cronin, T.M., Thunell, R., Vann, C., 2006. Modeling river discharge and precipitation from estuarine salinity in the northern Chesapeake Bay: application to Holocene paleoclimate. The Holocene 16,1-11. 
Saenger, C., Cronin, T.M., Willard, D., Halka, J., Kerhin, R. 2008. Increased terrestrial to ocean sediment fluxes in the northern Chesapeake Bay with twentieth century land alteration. Estuaries and Coasts. doi:10.1007/s12237-008-9048-5.

Saenger, C., Chang, P., Ji, L., Oppo, D.W., Cohen, A.L., 2009. Tropical Atlantic climate response to low-latitude and extratropical sea-surface temperature: a Little Ice Age perspective. Geophysical Research Letters 36, L11703. doi:10.1029/2009GL038677.

Sicre, M.-A., Jacob, J., Ezat, U., Rousse, S., Kissel, C., Yiou, P., Eiríksson, J., Knudsen, K.-L., Jansen, E., Turon, J.-L., 2008. Decadal variability of sea surface temperatures off North Iceland over the last 2000 years. Earth and Planetary Science Letters 268, 137-142.

Stuiver, M., Reimer, P.J., Braziunas, T.F., 1998. High-precision radiocarbon age calibration for terrestrial and marine samples. Radiocarbon 40,1127-1151.

Tedesco, K., Thunell, R., 2003. High resolution tropical climate record for the last 6 , 000 years. Geophysical Research Letters 30, 1891. doi:10.1029/2003GL017959.

Treydte, K.S., Schleser, G.H., Helle, G., Frank, D.C., Winiger, M., Haug, G.H., Esper, J., 2006. The twentieth century was the wettest period in northern Pakistan over the past millennium. Nature 440, 1179-1182.
Vann, C.D., Cronin, T.M., Dwyer, G.S., 2004. Population ecology and shell chemistry of a phytal ostracode species (Loxoconcha matagordensis) in the Chesapeake Bay watershed. Marine Micropaleontology 53, 261-277.

Wang, Y.J., Cheng, H., Edwards, R.L., He, Y.Q., Kong, X.G., An, Z.S., Wu, J.Y., Kelly, M.J. Dykoski, C.A., Li, X.D., 2005. The Holocene Asian monsoon: links to solar changes and North Atlantic climate. Science 308, 854-857.

Willard, D.A., Cronin, T.M., Verardo, S., 2003. Late Holocene climate and ecosystem variability from Chesapeake Bay sediment cores. The Holocene 13, 201-214.

Willard, D.A., Bernhardt, C.E., Korejwo, D., Meyers, S., 2005. Impact of millennial-scale Holocene climate variability on eastern North American terrestrial ecosystems. pollen-based climatic reconstruction. Global and Planetary Change 47, 17-35.

Zhang, R., Delworth, T.L., Held, I.M., 2007. Can the Atlantic Ocean drive the observed multidecadal variability in Northern Hemisphere mean temperature. Geophysical Research Letters 34, L02709. doi:10.1029/2006GL028683.

Zimmerman, A.R., Canuel, E.A., 2002. Sediment geochemical records of eutrophication in the mesohaline Chesapeake Bay. Limnology and Oceanography 47, 1084-1093. 